\title{
Sunflower Inbred Lines Screening for Tolerance to White Rot on Stalk
}

\author{
Boško Dedić · Dragana Miladinović · Siniša Jocić · Sreten Terzić · \\ Sonja Tančić $\cdot$ Nenad Dušanić $\cdot$ Vladimir Miklič
}

\begin{abstract}
received / primljeno: 02.11.2010. accepted / prihvaćeno: 14.12.2010. (C) 2011 IFVC

Summary: Seventy sunflower (Helianthus annuus L.) inbred lines were screened for tolerance to white rot on stalk. Plants were inoculated at the budding stage, with 4-day old Sclerotinia mycelium grown on PDA medium. Mycelium was placed on the leaf top and covered with tin foil, and the leaf was put into transparent nylon bag in order to maintain high humidity. Spot length on leaf was measured and plant tolerance was determined at the full flowering stage. Obtained results were analyzed by analysis of variance. Tested lines showed significant variability in response to disease. Eleven lines had lesion length less than $50 \%$ compared to susceptible control, so they could be considered tolerant and potentially interesting for breeding program.
\end{abstract}

Key words: Sclerotinia sclerotiorum, sunflower, tolerance, white rot

\section{Introduction}

Sclerotinia sclerotiorum (Lib.) De Bary is omnivorus fungi and the causal agent for diseases on more than 400 plant species (Boland \& Hall 1994). The fungus had been first identified on sunflower in 1861 (Purdy 1979) while in Serbia it was first described in 1948 (Aćimović 1998). It is common and widespread on sunflower and can attack all parts of plant. Midstalk rot is one of several forms of disease on sunflower and it is incited by the airborne ascospores. These spores are produced in apotecia developed on sclerotia in surface layer of soil. Dependence of apotecial formation on high humidity in the first few centimeters of soil for a certain period of time greatly limits regular appearance of disease, particularly in regions with drier climate. Disease could appear from seedling to maturity, but most commonly after period of flowering when the most devastating symptom is logging (Gulya et al. 1997). In high S. sclerotiorum infested sunflower fields under favourable conditions number of infected plants can reach up to 100\% (Maširević \& Gulya 1992, Rashid 1993).

B. Dedić $(\bowtie) \cdot$ D. Miladinović $\cdot$ S. Jocić $\cdot S$. Terzić $\cdot S$. Tančić $\cdot N$ Dušanić $\cdot$ V. Miklič

Institute of Field and Vegetable Crops, Maksima Gorkog 30, 21000 Novi Sad, Serbia

e-mail: bosko.dedic@ifvens.ns.ac.rs
Complete resistance has not yet been observed and partial resistance is under quantitative control (Bert et al. 2002, Mestries et al. 1998). There has been a great effort in searching for tolerance to midstalk rot both in cultivated sunflower and wild sunflower species. Hence, several methods of artificial inoculation have been developed (Degener et al. 1998, Castano et al. 1992b, Maširević \& Gulya 1992, Grauert et al. 1980, Castano et al. 2002, Vasić et al. 2004). To this date, a number of sunflower lines and hybrids with various levels of tolerance have been reported (Reimonte \& Castano 2008, Rönicke et al. 2004, Vear 2004), but level of tolerance is not yet considered adequate for control of the disease (Fick \& Miller 1997).

The aim of this study was to determine variability in response to $S$. sclerotiorum infection and to find tolerance within selected sunflower inbred lines.

\section{Materials and Methods}

\section{Sunflower Inbred Lines}

Seventy sunflower (Helianthus annuus L.) inbred lines were screened for tolerance to midstalk rot (Tab. 1). Tested inbred lines were created at Institute of Field and Vegetable Crops, Novi Sad, Serbia and have diverse origin. There was no prior information about their response to $S$. sclerotiorum infection of 
stem. Inbred line NSL 21, which was found to be highly susceptible to midstalk rot in field conditions (data not shown), was used as susceptible control.

\section{Experimental Plan}

The experiment was conducted on experimental field of Institute of Field and Vegetable Crops at Rimski Šančevi. The experiment was designed as completely randomized block system with three replications. Each experimental unit consisted of two 3.6 m length rows. Row spacing was
$0.7 \mathrm{~m}$ and space between plants in the row was $0.25 \mathrm{~m}$. Seeds of inbred lines were sown manually, three seeds per spot, in the first tenday period of April and thinned when plants fully developed first true pair of leaves.

\section{Inoculum and Inoculation}

Four-day old Sclerotinia mycelium grown on PDA medium was used for the inoculation. The fungal isolate used in this study was collected from infected stems of the plants grown at the same field where the test was performed. In total, 36 plants per line were inoculated

Table 1. Successfully inoculated genotypes and their reaction to leaf inoculation with $S$. sclerotiorum mycelium

Tabela 1. Uspešnost inokulacije i reakcija genotipova posle inokulacije sa micelijom gljive S. sclerotiorum

\begin{tabular}{|c|c|c|c|c|c|}
\hline $\begin{array}{l}\text { Genotype } \\
\text { Genotip }\end{array}$ & $\begin{array}{l}\text { Inoculation } \\
\text { Inokulacija }^{1}\end{array}$ & $\begin{array}{c}\text { Reaction of } \\
\text { inbred lines } \\
\text { Reakcija inbred } \\
\text { linija }^{2}\end{array}$ & $\begin{array}{l}\text { Genotype } \\
\text { Genotip }\end{array}$ & $\begin{array}{l}\text { Inoculation } \\
\text { Inokulacija }^{1}\end{array}$ & $\begin{array}{c}\text { Reaction of } \\
\text { inbred lines } \\
\text { Reakcija inbred } \\
\text { linija }^{2}\end{array}$ \\
\hline NSL1 & + & MS & NSL37 & $\mathrm{N}$ & $\mathrm{S}$ \\
\hline NSL2 & + & MS & NSL38 & + & $\mathrm{S}$ \\
\hline NSL3 & + & MS & NSL39 & + & MS \\
\hline NSL4 & + & MS & NSL40 & $\mathrm{N}$ & $\mathrm{S}$ \\
\hline NSL5 & + & MS & NSL41 & + & $\mathrm{S}$ \\
\hline NSL6 & + & MS & NSL42 & + & $\mathrm{S}$ \\
\hline NSL7 & + & $\mathrm{S}$ & NSL43 & + & MS \\
\hline NSL8 & + & $\mathrm{S}$ & NSL44 & $\mathrm{N}$ & $\mathrm{S}$ \\
\hline NSL9 & + & MS & NSL45 & + & MS \\
\hline NSL10 & + & $\mathrm{T}$ & NSL46 & + & MS \\
\hline NSL11 & + & $\mathrm{T}$ & NSL47 & + & MS \\
\hline NSL12 & + & MS & NSL48 & + & $\mathrm{S}$ \\
\hline NSL13 & + & $\mathrm{S}$ & NSL49 & + & $\mathrm{S}$ \\
\hline NSL14 & + & $\mathrm{T}$ & NSL50 & + & $\mathrm{S}$ \\
\hline NSL15 & + & MS & NSL51 & + & $\mathrm{S}$ \\
\hline NSL16 & + & MS & NSL52 & + & $\mathrm{T}$ \\
\hline NSL17 & $\mathrm{N}$ & $\mathrm{S}$ & NSL53 & + & $\mathrm{S}$ \\
\hline NSL18 & + & MS & NSL54 & + & HS \\
\hline NSL19 & $\mathrm{N}$ & $\mathrm{S}$ & NSL55 & + & $\mathrm{S}$ \\
\hline NSL20 & $\mathrm{N}$ & $\mathrm{S}$ & NSL56 & + & $\mathrm{S}$ \\
\hline NSL22 & $\mathrm{N}$ & S & NSL57 & + & $\mathrm{T}$ \\
\hline NSL23 & $\mathrm{N}$ & $\mathrm{S}$ & NSL58 & + & S \\
\hline NSL24 & + & MS & NSL59 & $\mathrm{N}$ & $\mathrm{S}$ \\
\hline NSL25 & + & $\mathrm{T}$ & NSL60 & + & S \\
\hline NSL26 & + & $\mathrm{T}$ & NSL61 & + & MS \\
\hline NSL27 & + & $\mathrm{T}$ & NSL62 & + & $\mathrm{S}$ \\
\hline NSL28 & + & MS & NSL63 & $\mathrm{N}$ & S \\
\hline NSL29 & + & MS & NSL64 & + & $\mathrm{T}$ \\
\hline NSL30 & $\mathrm{N}$ & S & NSL65 & + & $\mathrm{S}$ \\
\hline NSL31 & + & MS & NSL66 & + & MS \\
\hline NSL32 & $\mathrm{N}$ & $\mathrm{S}$ & NSL67 & + & MS \\
\hline NSL33 & + & $\mathrm{T}$ & NSL68 & + & MS \\
\hline NSL34 & + & MS & NSL69 & + & MS \\
\hline NSL35 & $\mathrm{N}$ & $\mathrm{S}$ & NSL70 & + & MS \\
\hline NSL36 & + & $\mathrm{T}$ & NSL21 $^{3}$ & + & $\mathrm{S}$ \\
\hline
\end{tabular}


at the budding stage, with diameter of bud approximately $5 \mathrm{~cm}$ (Mestries et al. 1998). Mycelium plugs from the edge of colony were placed on the leaf top and covered with tin foil, and the leaf was put into transparent nylon bag in order to achieve high humidity (Degener et al. 1998). In addition to this, experimental field was irrigated using sprinklers three times a week with average rate of $15 \mathrm{~mm}$ of water per week.

Data Recording and Statistical Analysis

Lesion length on leaf was measured periodically after inoculation and plant tolerance was determined at the full flowering stage, while percentage of plants without symptoms was recorded. Line NSL21 was used as a susceptible control. Statistical analysis was done using software Statistica 9.0.

\section{Results and Discussion}

Inoculation procedure was successful in 57 out of 70 tested inbred lines including control line, while other 13 lines had very low infection rate (Tab. 1). The lines with low infection rate were excluded from the experiment.

${ }^{1}+$ - successful inoculation, $\mathrm{N}$ - unsuccessful inoculation; ${ }^{2} \mathrm{~T}-$ tolerant genotype, MS medium susceptible genotype, $\mathrm{S}$ - susceptible genotype; ${ }^{3}$ susceptible control

$1+$ - uspešna inokulacija, N - neuspešna inokulacija; ${ }^{2} \mathrm{~T}-$ tolerantni genotipe, MS srednje osetljiv genotip, $\mathrm{S}-$ osetljiv genotip; ${ }^{3}$ osetljiva kontrola
Group of 11 lines (NSL52, NSL25, NSL10, NSL27, NSL36, NSL64, NSL57, NSL14, NSL11, NSL26, NSL33) had average relative length of lesion less than 50\% compared to lesion length of susceptible control. Eight lines (NSL 61 to NSL45) had relative lesion length very close to lower limit of $50 \%$ (46.4\% to $56.6 \%)$. These eight lines together with lines NSL 5 to NSL 68 could be considered as moderately susceptible, because their reaction to $S$. sclerotiorum was stronger in terms of lesion length than tolerant lines, although they had more than $25 \%$ shorter relative lesion length compared to susceptible control. Group of nine susceptible lines (NSL4, NSL58, NSL13, NSL48, NSL41, NSL42, NSL51, NSL53, NSL7) had relative length of lesion less than susceptible control $(80.3 \%$ to $97.9 \%)$, and group of eight lines (NSL60, NSL8, NSL50, NSL38, NSL62, NSL65, NSL49, NSL54) had the most severe symptoms of white rot $(100.4 \%$ to 126.8\%) (Fig. 1. and Tab. 1).

Average length of lesion on leaves was 6.25 $\mathrm{cm}$ for the most tolerant line and $29.13 \mathrm{~cm}$ for the most susceptible line (Fig. 2). The boxwhiskers plots for lines NSL52, (being the most tolerant one), NSL57, NSL24, NSL12, NSL16, NSL4, NSL53, and NSL50 show high value of standard error. This means that data varies in that extent that certainty for conclusion about tolerance/susceptibility reaction is greatly reduced. Furthermore, great number of outliers in case of lines NSL66, NSL67, NSL41, NSL21, NSL38, NSL49 also makes it difficult to reach a conclusion on reaction of the line in question (Fig. 2). These lines should be retested in order to achieve more coherent results.

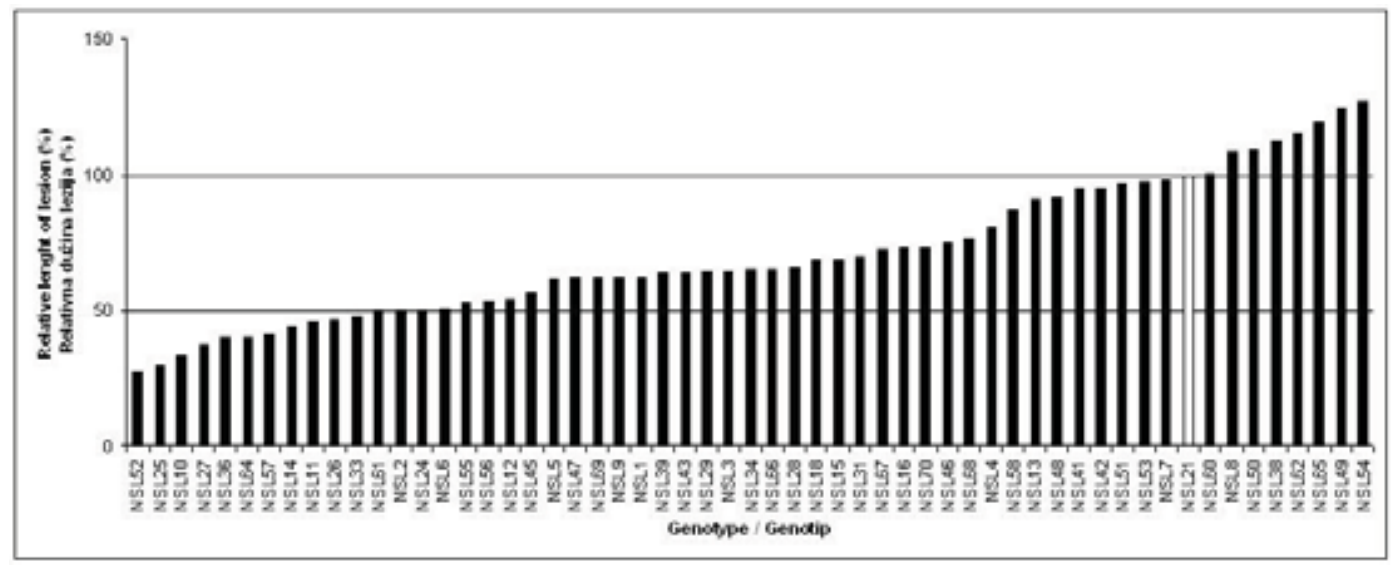

Fig. 1. Relative length of lesion along mid-vein showed as percentage of lesion length of tested line compared to lesion of susceptible control

Slika 1. Reletivna dužina pega duž srednjeg nerva prikazana kao odnos dužine lezije kod testirane linije i osetljive kontrole 
The existence of variability between different genotypes marked as moderately susceptible and susceptible could be seen from both figures. This type of reaction to $S$. sclerotiorum could be et al. 1998). Necessity of artificial inoculation of sunflower with $S$. sclerotinia is due to its high dependence on the environmental conditions for natural infection. Reliance on natural attack

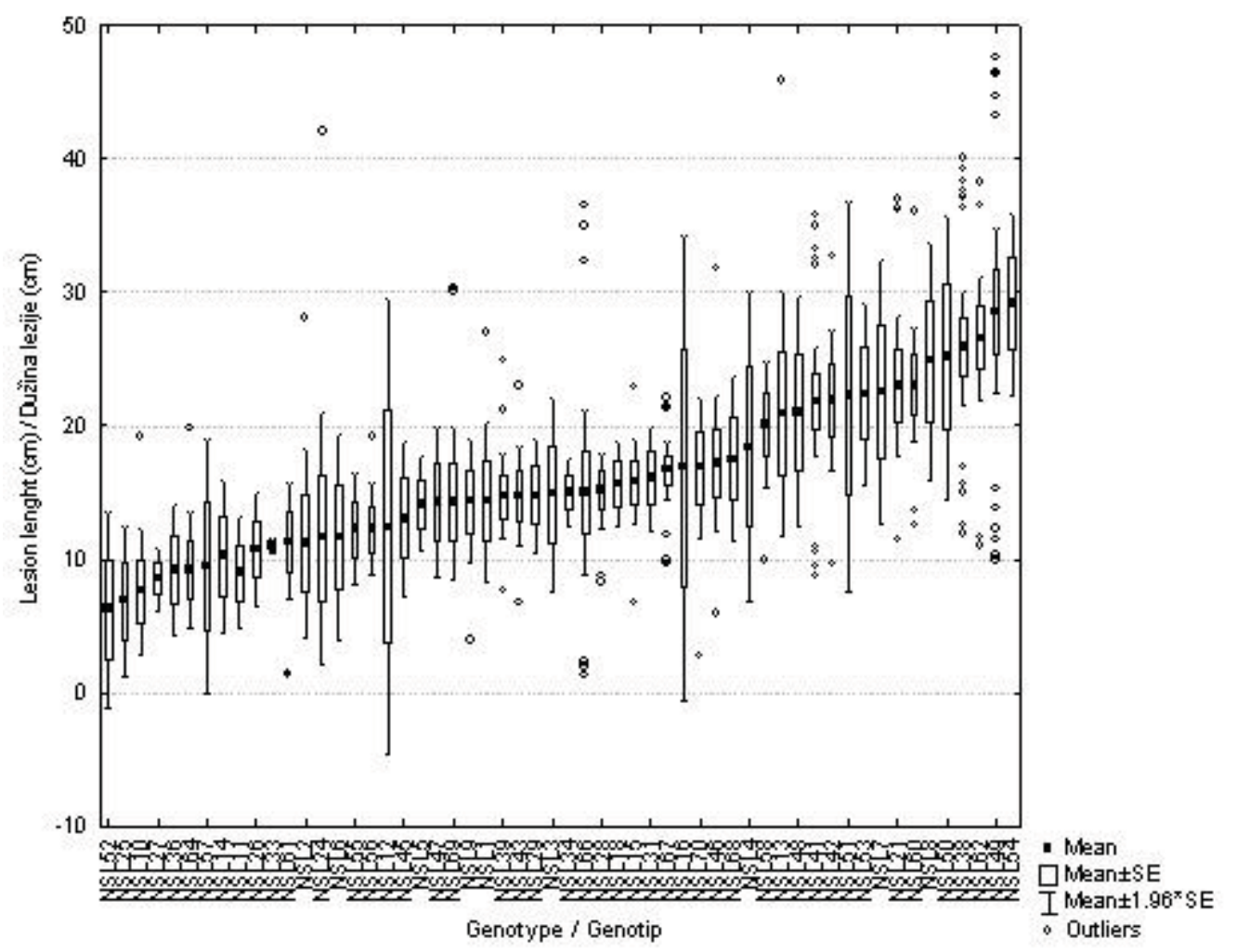

Fig. 2. Mean, standard error, 1.96 SE and outliers for length of lesion along mid-vein on leaf Slika 2. Prosek, standardna greška, 1,96 SE i vrednosti van intervala obuhvaćenog standardnom greškom dužine pege duž srednjeg nerva na listu

explained by inheritance of tolerance to this fungus. Studies have shown that tolerance is partial and polygenic, and levels of tolerance vary continually (Vear \& Tourvieille 1988, Achbani et al. 1996).

Breeding sunflower for tolerance to $S$. sclerotiorum is connected to various difficulties. The fungus causes rot on roots, stem, terminal bud and head, and all these are considered as separate diseases. Tolerance is mainly controlled by additive genes and screening for tolerance relies on various methods of artificial inoculation.

Suitable methods for artificial inoculation were developed in order to successfully test breeding material for disease tolerance in most cases. A good artificial inoculation test should produce high infection rate, be easy to handle and imitate natural disease incidence (Degener of fungus often results in inhomogeneous infection and could produce unreliable results (Serre et al. 2004). Natural attack is highly dependent on high humidity when disease progress is rapid and destructive, whereas dry period immediately after infection could completely stop the disease (Tourvieille et al. 1992). In our study there was complete absence of natural attack in the experimental field, presumably due to high temperatures and low RH during period when sunflower plants are most susceptible to mid-stalk rot. This indicates possible escape mechanism when there is source of inoculum but environmental factors are limiting appearance of the disease. Contrary to this, disease development was recorded on artificially inoculated leaves.

For the statistical analysis of lesion length we used only data from successfully inoculated plants. 
Leaf lesion is a reliable trait for screening against Sclerotinia and it is relatively simple compared with tests using ascospores on capitula (Castano et al. 1992b, Becelaere \& Miller 2004), and tests using mycelium on capitula in growth chamber (Vear \& Guillman 1977). However, reliability of this trait was not confirmed in the study of Degener et al. (1998) who found measurement of stem lesion more adequate.

Although different authors measured leaf lesions 4 to 7 days after inoculation (Degener et al. 1998, Castano et al. 1992a, Castano et al. 1992b, Caceres et al. 2006), in our case it was not possible due to slow progression of leaf lesions. One of the reasons for measuring leaf lesions later than 7 days after inoculation might be environmental conditions, especially high temperatures in the period immediately after artificial inoculation (Hahn 2002). However, disease progress was constant and symptoms were similar with the description of this disease. Small number of lines had lesion length lower than $50 \%$ compared to susceptible control. Lines that have less than one-half of the infection percentage of highly susceptible lines could be considered as the tolerant ones according to Miller (1992) and Castano et al. (1993). Taking into consideration significant correlation between lesion length and percentage of resistant plants, these lines can be considered tolerant to Sclerotinia midstalk rot.

It is known that responses to foliar and stem inoculations with mycelium are independent (Castaño et al. 1993). However, method of leaf inoculation is much closer to natural infection process than methods used for direct inoculation of stem. Moreover, methods used for direct inoculation of stem often imply artificial wounding in which case conclusion of some levels of tolerance might be lost.

Nevertheless, use of different methods might be needed as it is in the case with studying of white rot of head where results produced using inoculation with ascospores and mycelium proved to be complementary (Castano et al. 1993). Eleven tolerant lines were selected based on this study using method for leaf inoculation. Therefore, in order to narrow the selected lines and confirm these results, additional study using methods other than artificial inoculation of leaf will be done on all lines used in this study, with special consideration to those lines which proved to be tolerant in this study, for these lines can be used in breeding programs.

\section{References}

Achbani H, Tourvieille de Labrouche D, Vear F (1996): Tolerance of sunflower (Helianthus annuus L.) to terminal bud attack by Sclerotinia sclerotiorum (Lib.) de Bary. Europ. J. Plant Pathol. 102: 421-429

Aćimović M (1998): Bolesti suncokreta. Naučni institut za ratarstvo i povrtarstvo, Novi Sad

Becelaere G, Miller J F (2004): Methods of inoculation of sunflower heads with Sclerotinia sclerotiorum. Helia 27: 137-142

Bert P F, Jouan I, Tourvieille de Labrouche D, Serre F, Nicolas P, Vear F (2002): Comparative genetic analysis of quantitative traits in sunflower (Helianthus annuus L.) .1. QTL involved in tolerance to Sclerotinia sclerotiorum and Diaporthe belianthi. Theor. Appl. Genet. 105: 985-993

Boland G J, Hall R (1994): Index of plant hosts of Sclerotinia sclerotiorum. Can. J. Plant Pathol. 16: 93-108

Caceres C, Castano F, Rodriguez R, Ridao A, Salaberry T, Echeverria M, Colabelli M (2006): Variability of Sclerotinia responses in Helianthus petiolaris. Helia 29: 43-48

Castano F, Vear F, Tourvieille de Labrouche D (1992a): Relations between the reaction of sunflower genotypes to tests of tolerance to root and leaf attacks by Sclerotinia sclerotiorum. Proc 13th Int. Sunflower Conf., Piza, Italy, 1011-1016

Castano F M, Hemery-Tardin M C, Tourvieille de Labrouhe D, Vear F (1992b): The inheritance and biochemistry of tolerance to Sclerotinia sclerotiorum leaf infections in sunflower (Helianthus annuus L.). Euphytica 58: 209-219

Castano F, Vear F, Tourvieille D (1993): Tolerance of sunflower inbred lines to various forms of attack by Sclerotinia sclerotiorum and relations with some morphological characters. Euphytica 68: 85-98

Castano F, Baldini M, Re J, Vanozzi G P, Rodriguez R, Turi M, Tahmasebi-Enferadi S (2002): Genotypic responses and diallel analysis for an early tolerance test to Sclerotinia sclerotiorum in sunflower. Oléagineux, Corps Gras, Lipides 9: 474-478

Degener J, Melchinger E A, Gumber K R, Hahn V (1998): Breeding for Sclerotinia tolerance in sunflower: A modified screening test and assessment of genetic variation in current germplasm. Plant Breed. 117: 367-372

Fick G N, Miller J F (1997): Sunflower breeding. In: A. Schneiter (ed.), Sunflower Technology and Production, ASA-CSSA-SSSA, Madison, Wisconsin, USA, 395-440

Grauert P, Schlösser E, Schuster W (1980): Untersuchungen über die Anfälligkeit von Sorten und Linien der Sonnenblume (Helianthus annuus L.) gegenüber Sclerotinia sclerotiorum (Lib.) de Bary. Angew. Botanik 54: 349-364

Gulya T, Rashid K, Maširević S (1997): Sunflower diseases. In: A. Schneiter (ed.), Sunflower Technology and Production, ASA-CSSA-SSSA, Madison, Wisconsin, USA, 263-379

Hahn (2002): Genetic variation for resistance to Sclerotinia head rot in sunflower inbred lines. Field Crop. Res. 77: 153-159

Maširević S, Gulya T (1992): Sclerotinia and Phomopsis - two devastating sunflower pathogens. Field Crop. Res. 30: 271-300

Mestries E, Gentzbittel L, Tourvieille de Labrouche D, Nicolas P, Vear F (1998): Analyses of quantitative trait loci associated with tolerance to Sclerotinia sclerotiorum in sunflowers (Helianthus annuus L.) using molecular markers. Mol. Breed. 4: 215-226

Miller J F (1992): Breeding for Sclerotinia tolerance. Proc Sunflower Res. Workshop, Fargo, ND, USA, 10

Purdy L H (1979): Sclerorinia sclerotiorum: history, diseases and symptomatology, host range, geographic distribution and impact. Phytopathol. 69: 875-880

Rashid K Y (1993): Sclerotinia head rot and mid-stem infection of sunflower in Manitoba. Proc 15th Sunflower Res. Workshop, Fargo, ND, USA 
Reimonte G, Castano F (2008): Susceptibility of sunflower (Helianthus annuus) hybrids to mid stem rot and broken stem caused by Sclerotinia sclerotiorum. Cien. Inv. Agr. 35: 21-28

Rönicke S, Hahn V, Horn R, Gröne I, Brahm L, Schnabl H, Friedt W (2004): Interspecific hybrids of sunflower as a source of Sclerotinia sclerotiorum. Plant Breed. 123: 152-157

Serre F, Walser P, Tourvieille de Labrouche D, Vear F (2004): Sclerotinia sclerotiorum capitulum tolerance tests using ascospores: results over the period 1991-2003. Proc 16th Int. Sunflower Conf., Fargo, North Dakota, USA 129-133

Tourvieille D, Vear F, Achbani E H (1992): Attack of sunflower terminal buds by Sclerotinia sclerotiorumi in sunflowers. Proc13th Sunflower Conference, Pisa, Italy, 859-864

Vasić D, Jocić S, Malenčić Đ, Pajević S, Miladinović F, Škorić
D (2004): Testiranje na otpornost prema Sclerotinia različitih genotipova suncokreta. Zbornik radova Instituta za ratarstvo i povrtarstvo, Novi Sad 40: 291-300

Vear F (2004): Breeding for durable tolerance to main diseases of sunflower. Proc 16th Int. Sunflower Conf., Fargo, North Dakota, USA, 15-28

Vear F, Guillaumin J J (1977): Development of a test useable in breeding for tolerance to sunflower capitulum attack by Sclerotinia sclerotiorum. Proc 7 th Int. Sunflower Conf., Krasnodar, USSR, 205-212

Vear F, Tourvieille D (1988): Heredity of tolerance to Sclerotinia sclerotiorum in sunflower. II Study of capitulum tolerance to natural and artificial ascospore infections. Agronomie 8: 503-508

\title{
Testiranje inbred linija suncokreta na tolerantnost prema beloj truleži stabla
}

\author{
Boško Dedić · Dragana Miladinović · Siniša Jocić $\cdot$ Sreten Terzić $\cdot$ \\ Sonja Tančić $\cdot$ Nenad Dušanić $\cdot$ Vladimir Miklič
}

Institut za ratarstvo i povrtarstvo, Maksima Gorkog 30, 21000 Novi Sad, Srbija

Izvod: Sedamdeset inbred linija suncokreta (Helianthus annuus L.) je testirano na tolerantnost prema prouzrokovaču bele truleži stabla. Biljke su inokulisane u fazi butonizacije sa 4 dana starom kolonijom gljive gajenom na PDA podlozi. Delovi podloge sa micelijom su stavljeni na vrh lista, prekriveni aluminijumskom folijom i potom providnom najlonskom kesom da bi se obezbedio visok nivo vlažnosti. Merena je dužina pega i nivo tolerantnosti u fazi punog cvetanja suncokreta. Testirane linije su pokazale značajnu varijabilnost u reakciji prema patogenu, a 11 linija čija je prosečna relativna dužina pega iznosila ispod 50\% u odnosu na osetljivu kontrolu su označene kao tolerantne i potencijalno interesantne za uključivanje u proces oplemenjivanja.

Ključne reči: bela trulež stabla, Sclerotinia sclerotiorum, suncokret, tolerantnost 